\title{
THE WEATHERING OF A SULFIDE OREBODY: SPECIATION AND FATE OF SOME POTENTIAL CONTAMINANTS
}

\author{
AlEXANDRA COURTIN-NOMADE ${ }^{\S}$ AND CÉCILE GROSBOIS \\ Université de Limoges, Groupement de Recherche Eau Sol Environnement (GRESE), IFR 145 GEIST, FST, \\ 123, avenue A. Thomas, F-87060 Limoges Cedex, France
}

MATTHEW A. MARCUS AND SIRINE C. FAKRA

Advanced Light Source, Lawrence Berkeley National Lab, 1 Cyclotron Road, Berkeley, California 94720, USA

JEAN-MICHEL BENY

CNRS, Institut des Sciences de la Terre d'Orléans, 1A, rue de la Férollerie, F-45071 Orléans Cedex 2, France

ANDREA L. FOSTER

Mineral Resources Division, U.S. Geological Survey, 345 Middlefield Road, Menlo Park, California 94025, USA

\begin{abstract}
Various potentially toxic trace elements such as $\mathrm{As}, \mathrm{Cu}, \mathrm{Pb}$ and $\mathrm{Zn}$ have been remobilized by the weathering of a sulfide orebody that was only partially mined at Leona Heights, California. As a result, this body has both natural and anthropogenically modified weathering profiles only $500 \mathrm{~m}$ apart. The orebody is located in a heavily urbanized area in suburban Oakland, and directly affects water quality in at least one stream by producing acidic conditions and relatively high concentrations of dissolved elements (e.g., $\sim 500 \mu \mathrm{g} / \mathrm{L} \mathrm{Cu}, \sim 3700 \mu \mathrm{g} / \mathrm{L} \mathrm{Zn}$ ). Micrometric-scale mineralogical investigations were performed on the authigenic metal-bearing phases (less than $10 \mu \mathrm{m}$ in size) using electron-probe micro-analysis (EPMA), micro-Raman, micro X-ray absorption spectroscopy ( $\mu$ XAS), scanning X-ray diffraction ( $\mu$ SXRD) and scanning X-ray fluorescence ( $\mu$ SXRF) mapping techniques. Those measurements were coupled with classical mineralogical laboratory techniques, X-ray diffraction (XRD) and scanning electron microscopy (SEM). Authigenic metal-bearing phases identified are mainly sulfates (jarosite, epsomite, schwertmannite), Fe (oxy-)hydroxides (goethite, hematite and poorly crystalline Fe products) and poorly crystalline Mn (hydr-)oxides. Sulfates and Fe (oxy-)hydroxides are the two main secondary products at both sites, whereas Mn (hydr-) oxides were only observed in the samples from the non-mining site. In these samples, the various trace elements show different affinities for Fe or Mn compounds. Lead is preferentially associated with Mn (hydr-)oxides and As with Fe (oxy-)hydroxides or sulfates. Copper association with $\mathrm{Mn}$ and $\mathrm{Fe}$ phases is questionable, and the results obtained rather indicate that $\mathrm{Cu}$ is present as individual $\mathrm{Cu}$-rich grains (Cu hydroxides). Some ochreous precipitates were found at both sites and correspond to a mixture of schwertmannite, goethite and jarosite containing some potentially toxic trace elements such as $\mathrm{Cu}, \mathrm{Pb}$ and $\mathrm{Zn}$. According to the trace element distribution and relative abundance of the unweathered sulfides, this orebody still represents a significant reservoir of potential contaminants for the watershed, especially in the non-mining site, as a much greater proportion of sulfides is left to react and because of the lower porosity in this site.
\end{abstract}

Keywords: potentially toxic trace elements, acid mine-drainage, Fe and Mn oxides, jarosite, micro-Raman spectra, California.

$\S \quad$ E-mail address: alexandra.courtin@unilim.fr 


\section{INTRODUCTION}

Toxic metals in acid mine-drainage (AMD) cause detrimental environmental effects to ground and surface waters. The alteration of sulfide-bearing rocks under oxidizing conditions generates low-pH solutions that may contain potentially toxic trace elements (PTTE), usually metals and metalloids. Of primary importance in addressing issues of environmental concern and health safety is the release of PTTE such as As, $\mathrm{Cu}$, $\mathrm{Pb}$ and $\mathrm{Zn}$. Element mobility depends on a complex array of biotic and abiotic sorption and coprecipitation onto different solid phases, such as iron (oxy-) hydroxides, sulfates, and clays (e.g., Bhumbla \& Keefer 1994, Hudson-Edwards et al. 1999, Brown et al. 1999, Nachtegaal \& Sparks 2004, Serrano et al. 2005). The stability of PTTE-hosting minerals depends on several geochemical parameters, such as $\mathrm{pH}, \mathrm{Eh}$, and ionic strength (e.g., Veeresh et al. 2003, Nachtegaal \& Sparks 2004), microbial activities (Lalonde et al. 2007, Jones \& Renaut 2007) and climatic conditions (wet-dry cycling, temperature) (Dold \& Fontboté 2001, Moncur et al. 2005). In order to understand (and ideally prevent) remobilization of trace elements, one needs additional knowledge of trace-element sources, reaction rates and mineralogical pathways. Therefore, a clear identification of the trace element carriers is essential to forecast their mobility during weathering processes.

In a single watershed, a sulfide orebody exposed to two different environments was studied: one affected by AMD as a consequence of former mining activities, and one from natural unaffected outcrops. We will refer to mine-affected and unaffected as MA and UA, respectively. Water runoff from the former exploitation has resulted in the precipitation of ochreous deposits in a local stream down-slope from the pile of waste rock at the MA site. In the UA site, weathering of the unexploited orebody has generated an ironpan several $\mathrm{m}$ thick. The study of the same sulfide orebody, weathered under different conditions, has been undertaken in order to (1) evaluate the fate and the behavior of potentially toxic trace metals and (2) determine the mineralogical variations and environmental consequences at the two sites. In this study, we also aim to investigate the sources of the various metals and metalloids (mainly $\mathrm{As}, \mathrm{Cu}$, $\mathrm{Pb}$ and $\mathrm{Zn})$.

\section{Materials AND Method}

\section{Field site and sampling}

The site belongs to the Great Valley sequence of geological units in California (Fig. 1). The Leona Heights mine in the Oakland area, now abandoned, exploited a localized sulfide orebody (mainly pyrite), occurring within a keratophyre and quartz keratophyre complex, the Leona "rhyolite", a massive basalt (Graymer 2000) for sulfuric acid from the late 1800s through the late 1920s (Hauri 2001). This small body of pyrite also contains some chalcopyrite, bornite, sphalerite, chalcocite and native copper (Clark 1917). About $15 \mathrm{~km}$ of mineshafts, tunnels and a pile of waste rock $50 \mathrm{~m}$ high are the leftovers of these past mining activities. The ore is located above the Knoxville Formation, mainly consisting of volcanogenic and sedimentary units with minor conglomerate (Graymer 2000). Those units are affected by secondary strike-slip faults associated with the Hayward fault system. The pyrite bodies, some more than $30 \mathrm{~m}$ across, appear as veins in the rhyolite (Fig. 1).

The site experiences a temperate climate with annual rainfall around $422 \mathrm{~mm} /$ year (average data on the last century 1908-2008; http://climvis.ncdc.noaa.gov/). The rainy period lasts from November to the end of April, the rest of the year being dry. 


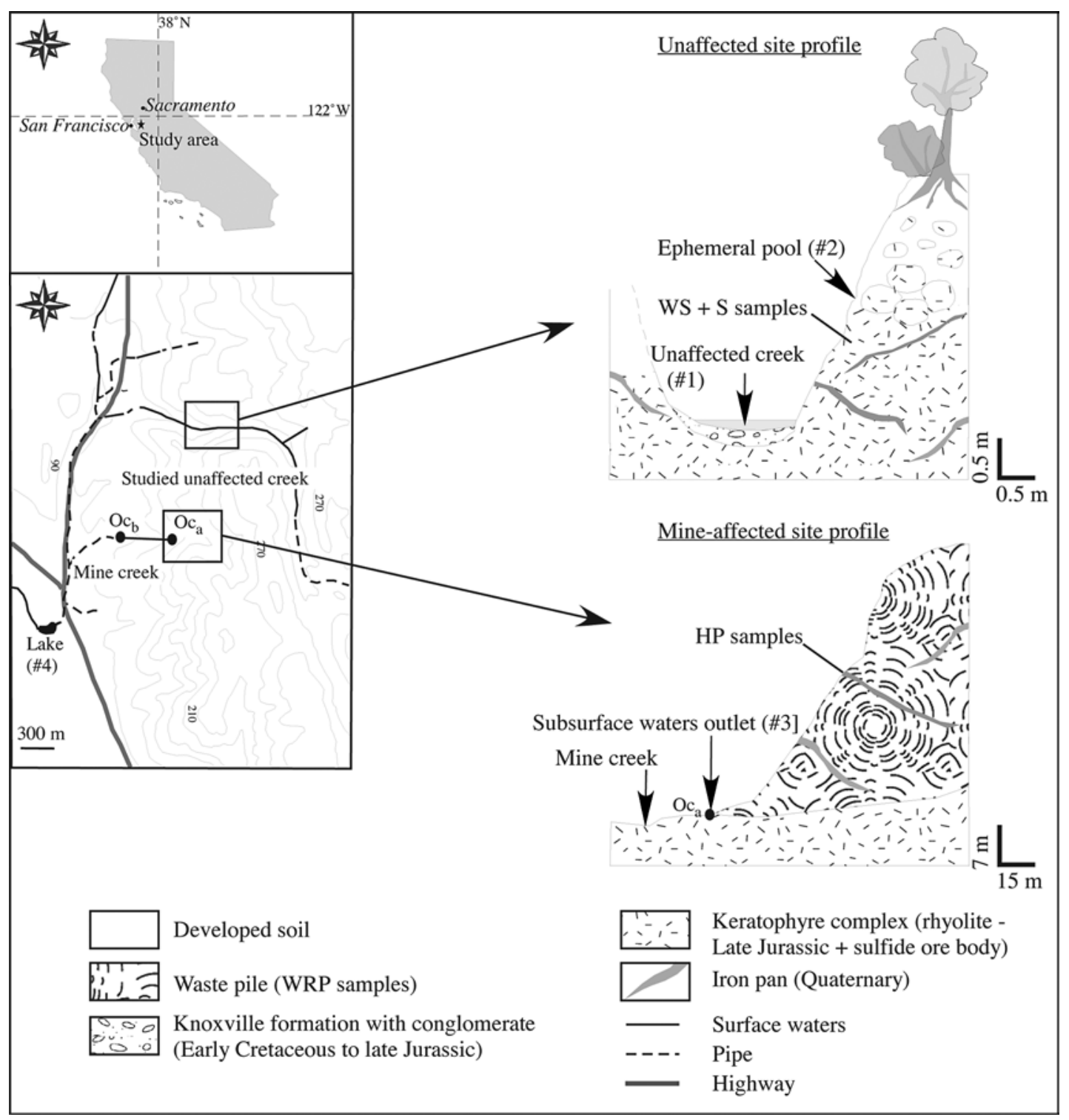

FIG. 1. Location of the study area, in the Great Valley Sequence, California, USA. The small creek that drains the watershed containing the mine is the only one impacted by AMD. Sample locations are indicated as \#1 to \#4. Ochre samples were collected at locations $\mathrm{Oc}_{\mathrm{a}}$ and $\mathrm{Oc}_{\mathrm{b}}$. The unaffected site (UA) makes up the majority of the flow that drains into the lake. It drains across the ironpan and the sulfide orebody. Abbreviations: WRP: waste-rock pile, HP: hardpan, S: unweathered rhyolitesulfide orebody complex, WS: weathered rhyolite-sulfide orebody complex, $\mathrm{Oc}_{\mathrm{a}}$ and $\mathrm{Oc}_{\mathrm{b}}$ : ochres at locations a and $\mathrm{b}$.

\section{The mine-affected (MA) site}

The pile of waste rock material consists only of crushed products of excavation. Most of the pile at the mining site is always unsaturated, but owing to seasonal rain events, the pile is divided in two by a channel several $\mathrm{m}$ wide created by water runoff. Additional secondary channels are also present through the waste pile. Because of the heterogeneity in color and particle size, samples were collected from top to bottom of the pile. Part of the waste rock, which is coarsely granular, is cemented by thin crusts developed all along the slope. 
These thin crusts are hardpans and have been sampled in the main water channel.

Downhill from the pile of waste rock at the mining site, a small creek drains the orebody, winds through the neighborhood, and has a layer of ochreous precipitate in its bed a few $\mathrm{cm}$ thick. The main supply of the mine creek is groundwater from buried mine-shafts that reaches the surface at an outlet downstream of the tailings (Fig. 1, at sample location $\mathrm{Oc}_{\mathrm{a}}$ and \#3). In contact with atmospheric conditions, sulfides within the mine dump are oxidized, weathered and leached by superficial waters that become acidic, generating typical AMD. Two samples of ochre precipitates were collected. The first sample $\left(\mathrm{Oc}_{\mathrm{a}}\right.$; Fig. 1$)$ was collected directly at the outlet. The second sample $\left(\mathrm{Oc}_{\mathrm{b}}\right.$; see Fig. 1) was collected downstream on the creek banks, just before the creek goes underground, and therefore was more exposed to seasonal dryness and flood events than sample $\mathrm{Oc}_{\mathrm{a}}$. The mine creek exhibits an acidic $\mathrm{pH}$ of $\sim 3.8$ and high electrical conductivity (E.C.) of 1394 $\mu \mathrm{S} / \mathrm{cm}$. Also, several contaminants were detected in the mine creek (Table $1, \# 3)$. Its flow $(0.3 \mathrm{~L} / \mathrm{s})$ has been measured to be approximately 8.3 times smaller than that of UA creek (2.5 L/s, Hauri 2001).

This small acidic creek meets with a large stream originating from the gathering of the two UA creeks, about $300 \mathrm{~m}$ downstream (Fig. 1).

\section{The unaffected (UA) site}

he UA creek site studied has developed an ironpan several $m$ thick over the massive sulfide deposit, which generates AMD where exposed to runoff. Interstitial and groundwater runoffs in this area, which infiltrate the massive sulfide deposit, show the lowest measured $\mathrm{pH}$, around 2 (E.C. not available here) (Table 1, \#2). These waters also have the highest concentrations of numerous metals, generally far above Environmental Protection Agency (EPA) regulation limits (U.S. EPA. 2002; Table 1). This acidic drainage is rapidly diluted when mixing with the main flow of the creek (with a neutral $\mathrm{pH}, c a$. 6.1 and an E.C. of $579 \mu \mathrm{S} / \mathrm{cm}$, lower than that of the mine samples: Table 1,\#1). Downstream, the combined creeks drain into a small lake. Regardless of the different sampling locations considered (mining-affected or not) the analyses of water show an effective release of the contaminants studied, even if a dilution occurs for most of the dissolved contaminants. Furthermore, in previous hydrological surveys, Hauri (2001) and Butler (2006) pointed out the high toxicity of the mine waters to aquatic organisms, a chronic toxicity in the lake but no toxicity for samples from the non-impacted creek. At the UA site, both the rhyolite-sulfide orebody complex and ironpan samples were collected at different locations from uphill to downhill according to variations in the mineralogical composition and color.

\section{Experimental methods}

Water samples were collected at both sites once during the dry season period (end of July). Each sample was collected in duplicate, filtered in situ on $0.2 \mu \mathrm{m}$ cellulose acetate filters, acidified with $\mathrm{HCl}$ for trace element analysis and stored in acid-washed vials.

$\mathrm{pH}$ and electrical conductivity. The $\mathrm{pH}$ was measured in situ using a HI 1230B combined electrode $(3 \mathrm{M} \mathrm{KCl})$ connected to a $\mathrm{HI} 9025 \mathrm{C} \mathrm{pH} / \mathrm{mV}$ meter. Electrical conductivity and temperature were measured with a microprocessor conductivity meter (HI 933100).

TABLE 1. MAJOR- AND TRACE-ELEMENT COMPOSITION OF THE DRY-SEASON WATER SAMPLES $(07 / 22 / 04)$

\begin{tabular}{|c|c|c|c|c|c|c|c|c|c|c|c|c|}
\hline Site & $\mathrm{Fe}_{\mathrm{d}}$ & $\mathrm{Mg}^{2+}$ & $\mathrm{Na}^{+}$ & $\mathrm{K}^{+}$ & $\mathrm{Mn}_{\mathrm{d}}$ & $\mathrm{SO}_{4}{ }^{2-}$ & As & $\mathrm{Cu}$ & $\mathrm{Pb}$ & $\mathrm{Zn}$ & $\mathrm{pH}$ & E.C. \\
\hline$\# 1$ & 15 & 33 & 33 & 1.6 & 132 & 126 & 0.2 & 119 & 0.1 & 140 & 6.1 & 579 \\
\hline$\# 2$ & 8631 & 215 & 55 & 5.6 & 9021 & 3715 & 3409.3 & 19164 & 2.6 & 27485 & 2.0 & n.a. \\
\hline$\# 3$ & 130 & 101 & 38 & 4.0 & 2941 & 950 & 0.6 & 507 & 0.2 & 3728 & 3.8 & 1394 \\
\hline$\# 4$ & n.a. & 66 & 38 & 2.0 & 50 & 267 & 0.3 & 18 & 0.1 & 138 & 7.3 & 840 \\
\hline \multicolumn{13}{|c|}{ SLRS 4} \\
\hline \multirow{2}{*}{\multicolumn{2}{|c|}{ certified }} & & & & & & 0.68 & 1.81 & 0.086 & 0.93 & & \\
\hline & & & & & & & \pm 0.06 & \pm 0.08 & \pm 0.007 & \pm 0.10 & & \\
\hline \multicolumn{2}{|c|}{ measured } & & & & & & 0.74 & 1.63 & 0.05 & 1.29 & & \\
\hline \multicolumn{2}{|c|}{$\mathrm{MCL}$} & & & & & & 10 & 1.3 & 15 & n.d. & & \\
\hline
\end{tabular}

\#1: Unaffected site (main stream), \#2: Unaffected site (interstitial waters), \#3: Mine creek (mine outlet), \#4: Lake (see Fig.1 for sample locations). SLRS: international certified reference waters (SLRS-4) reference and measured values. MCL: maximum levels of contaminant in drinking water ( $\mathrm{mg} / \mathrm{L}$ for $\mathrm{Cr}, \mathrm{Ni}$ and $\mathrm{Cu} ; \mathrm{mg} / \mathrm{L}$ for $\mathrm{As}, \mathrm{Cd}$ and $\mathrm{Pb}$ ) as defined by the U.S. Environmental Protection Agency (2002); n.a.: not analyzed; $n$.d.: not determined; d: total dissolved element. Units: concentrations of $\mathrm{Fe}_{\mathrm{d}}, \mathrm{Mg}^{2+}, \mathrm{Na}^{+}, \mathrm{K}^{+}$, $\mathrm{Mn}_{\mathrm{d}}$ and $\mathrm{SO}_{4}{ }^{2-}$ are expressed in $\mathrm{mg} / \mathrm{L}$, and those of $\mathrm{As}, \mathrm{Cu}, \mathrm{Pb}$ and $\mathrm{Z} n$, in $\mu \mathrm{g} / \mathrm{L}$. E.C.: electrical conductivity, expressed in $\mu \mathrm{S} / \mathrm{cm}$. 
ICP. Dissolved trace element concentrations were analyzed by ICP-MS (Thermo X7). Analytical quality was evaluated by analyses of the median standard every five unknown samples and international certified reference waters (SLRS-4, LGC 6019). Accuracy was within $5 \%$ of the certified values (Table 1) and the analytical error, relative to standard deviation, better than $5 \%$ for concentrations 10 times higher than the detection limits.

Because of the heterogeneity in color and grain size at the both sites, various categories of solid samples were collected at both sites. Bulk chemical compositions of solid samples were obtained on crushed samples $(<63 \mu \mathrm{m})$ at the analytical facility of SARM-CRPG (Vandœuvre-lès-Nancy, France). Total contents of major elements were established by ICP-AES (Jobin-Yvon 70; Govindaraju \& Melvelle 1987), and that of trace elements, by ICP-MS (Perkin Elmer 5000, Govindaraju et al. 1994). Total organic carbon (TOC, with a previous $\mathrm{HCl}$ treatment to eliminate carbonates) and total sulfur (TS) were analyzed by $\mathrm{O}_{2}$ flow combustion at $1400^{\circ} \mathrm{C}$ using a LECO SC 144 DR.

$X R D$. Powder samples were characterized by $\mathrm{X}$-ray diffraction (XRD) using $\mathrm{Cu} K \alpha_{1,2}$ radiation (step size of $0.04^{\circ} 2 \theta$; counting time $4 \mathrm{~s}$ ) on a Siemens D5000 diffractometer equipped with a diffracted-beam graphite monochromator.

Raman. To identify the mineralogical content at a finer scale (1 $\mu \mathrm{m}$ spot size), we used a Raman microspectrometer (XY 800 Dilor) equipped with an Ar green laser $(514.5 \mathrm{~nm})$ focused at the micrometer scale. The laser power was limited to $2-5 \mathrm{~mW}$ to avoid local heating of the sample (Courtin-Nomade et al. 2003). Scans were usually recorded in the range 60 to $1579 \mathrm{~cm}^{-1}$; each scan was about 15 minutes long (300 $s$ per window).

SEM-EDAX. A Philips XL-30 scanning electron microscope (SEM) coupled to an energy-dispersive $\mathrm{X}$-ray analyzer system (EDAX) was used to obtain secondary (SE) and back-scattered electron (BSE) analyses for morphological and semiquantitative chemical information. These observations were carried out on polished thin sections that were made after the material was embedded in an epoxy resin, which cures at room temperature to avoid modification of the chemical speciation of the elements studied.

EPMA. Electron-Probe Microanalysis (EPMA) was used to obtain in situ analyses of minerals for the major and trace elements (CAMECA SX-50 equipped with an EDAX system and four wavelength-dispersive spectrometers operating at $15 \mathrm{kV}$ and $4 \mathrm{nA}$ beam current settings for major elements). The instrument was calibrated using standard reference materials, including natural and synthetic silicates, oxides and sulfide minerals. Concentrations of trace elements below 1000 $\mathrm{mg} / \mathrm{kg}$ were obtained with a voltage of $35 \mathrm{kV}$ and a beam current of $500 \mathrm{nA}$ using the procedure developed by Fialin et al. (1999). In this procedure, ten spots are probed for ten seconds each, and the data are combined into a single set.

Material synthesis. Synthetic goethite and two-line ferrihydrite (HFO) were prepared for $\mu$ XAS measurements according to the Schwertman \& Cornell (2000) protocol. Amorphous manganese dioxide was synthesized according to the protocol developed by Davranche \& Bollinger (2000). Arsenic, $\mathrm{Cu}$ and $\mathrm{Pb}$ were added before solid precipitation (coprecipitation), or the elements were added after precipitation with a $24-\mathrm{h}$ contact time (adsorption). The salts of the elements were $\mathrm{Na}_{2} \mathrm{HAsO}_{4} \cdot 7 \mathrm{H}_{2} \mathrm{O}$ [puriss. p.a., ACS reagent, $\geq 98.5 \%$ (RT), Fluka], $\mathrm{Cu}\left(\mathrm{NO}_{3}\right)_{2} \bullet 2.5 \mathrm{H}_{2} \mathrm{O}$ (ACS reagent, $98.0 \%$, Sigma-Aldrich) and $\mathrm{Pb}\left(\mathrm{NO}_{3}\right)_{2}$ (ACS reagent, $\geq 99.0 \%$, Sigma-Aldrich). The amounts of the various metals and metalloid were adjusted according to bulk chemical analyses on the natural samples in order to mimic the levels of the trace elements in the samples studied.

$\mu S X R F$ and $\mu X A S$. Synchrotron-based $\mu$ SXRF and $\mu X A S$ measurements were carried out on beamline 10.3.2 of the Advanced Light Source (ALS), Lawrence Berkeley National Lab, Berkeley, California (Marcus et al. 2004). The standards used to determine the speciation of the various elements studied were previously described in the materials synthesis paragraph of this section except for the zero valence of $\mathrm{Cu}$, for which a foil was used.

Samples were mounted onto an XYZ stage oriented $45 \%$ to the beam. Micro-SXRF elemental maps were obtained by scanning a thin section $30 \mu \mathrm{m}$ thick under a monochromatic beam with an incident energy of 13.085 $\mathrm{keV}$ and a beam spot-size on the sample of $5 \mu \mathrm{m}(\mathrm{H})$ $\times 5 \mu \mathrm{m}(\mathrm{V})$ full width at half maximum (FWHM). The step size was $5 \times 5 \mu \mathrm{m}$ and the dwell time per point was $50 \mathrm{~ms}$. The characteristic intensities of the $K \alpha$ fluorescence line of the elements of interest (As, $\mathrm{Cu}$, $\mathrm{Fe}, \mathrm{Mn}$ and $\mathrm{Pb}$ ) were windowed and measured with a seven-element $\mathrm{Ge}$ solid-state detector. $\mathrm{As} \mathrm{Pb} L_{3}$ and $\mathrm{As}$ $K$ fluorescence energies overlap, we acquired XRF maps of the same area at energies just above and just below the $\mathrm{Pb} L_{3}$ edge in order to separate $\mathrm{Pb}$ from As. Data on solid speciation for $\mathrm{As}, \mathrm{Cu}$ and $\mathrm{Mn}$ were obtained by recording the corresponding elemental $K$-edge extended XANES. For lead, solid-speciation data were obtained by recording $\mathrm{Pb} L_{3}$ edge extended XANES spectra on several $7 \mu \mathrm{m} \times 7 \mu \mathrm{m}$ spots. Data analysis was performed using the 10.3.2 LabView software suite (http://xraysweb.lbl.gov/uxas/Beamline/Software/ Software.htm) and other standard XAFS software (e.g., Athena or SixPack).

$\mu S X R D$. Micro-SXRD analyses were performed on the former ALS beamline 7.3.3 (now 12.3.2), Lawrence Berkeley National Lab (Tamura et al. 2005). MicroXRD patterns were collected in reflection geometry. Micro-SXRD maps were collected on polished thin sections $30 \mu \mathrm{m}$ thick mounted onto an XYZ stage horizontally tilted at $10^{\circ}$, with an incident $\mathrm{X}$-ray energy of 6 $\mathrm{keV}$, a beam size of $6 \mu \mathrm{m}(\mathrm{H}) \times 6 \mu \mathrm{m}(\mathrm{V})$ and a 1024 
$\times 1024$ pixel Mar133 CCD detector. The acquisition time per map varied from 10 to 18 hours, depending on the size of the area probed. XRD profiles were extracted and calibrated using the software XMAS (Tamura et al. 2005) and a NIST $\mathrm{LaB}_{6}$ powder calibration material.

\section{Results And Discussion}

\section{Morphological and mineralogical characteristics of the two sites}

The MA and UA sites exhibit differences in structure, texture of the materials and degree of water-rock interactions, as summarized in Table 2. These structural characteristics are only attributed to extraction processes. The porosity at the MA site is predominantly due to crushed excavation rocks. By comparison, the material of the UA site is massive, allowing water circulation only along the fractures. The UA site is located in a forest, and a soil has developed on the rhyolitesulfide orebody complex. A network of roots favored the mechanical and subsequent chemical erosion along fracture of the parent rock.

The bulk chemical and mineralogical compositions of the materials from both sites are presented in Table 3. At the MA site, all three types of material, namely waste rock pile (WRP) (i), hardpans (HP) (ii) and ochres (Oc) (iii), exhibit high loss on ignition (LOI) attributed to a large amount of hydroxylated or hydrated minerals. From uphill to downhill of the dump, no spatial gradient in the distribution of various trace elements was observed.

(i) The waste-rock pile is composed mainly of primary minerals such as quartz, feldspars and micas, but secondary sulfates (jarosite, alunogen) and goethite also were identified.

(ii) The hardpan samples are Fe-rich crusts with cements composed of goethite and jarosite. Some of the $\mathrm{Fe}$ (oxy-)hydroxides exhibit typical colloform textures, characteristic of authigenic precipitation from colloidal solution (Ramdohr 1969).

(iii) The $\mathrm{X}$-ray diffractogram obtained on ochre sample $\mathrm{Oc}_{\mathrm{a}}$ shows quartz as detrital grains, goethite, schwertmannite and jarosite. The X-ray diffractogram obtained on sample $\mathrm{Oc}_{\mathrm{b}}$ (not shown) clearly indicates

TABLE 2. MAIN DIFFERENCES BETWEEN THE TWO SITES STUDIED

\begin{tabular}{lll}
\hline & \multicolumn{1}{c}{ Mine-affected site (MA) } & Unaffected site (UA) \\
\hline Structure & $\begin{array}{l}\text { Crushed material de rived from } \\
\text { excavation during exploitation }\end{array}$ & Massive rock \\
Texture & $\begin{array}{l}\text { Great heterogeneity in grain } \\
\text { size, from blocks to fine fractions } \\
(<2 \mu \mathrm{m}) \Rightarrow \text { grain porosity (high) }\end{array}$ & Shear porosity (tow) \\
$\begin{array}{l}\text { Water-rock } \\
\text { inferaction }\end{array}$ & $\begin{array}{l}\text { Dry-wet cycle; temporary leaching } \\
\text { during episodes of rainfall }\end{array}$ & $\begin{array}{l}\text { Continuous leaching by } \\
\text { interstitial waters and local } \\
\text { creek }\end{array}$ \\
\hline
\end{tabular}

the presence of poorly crystalline material (broad bands between $2.8 \AA$ and $2.5 \AA$, and near $1.7 \AA$ ) along with the presence again of detrital grains such as quartz and feldspars associated with goethite (which is the main mineral) and jarosite, but no schwertmannite (Table 3).

At the UA site, only rhyolite-sulfide ore body complex (weathered or not) and ironpan (IP) materials are present. The state of weathering of the sulfides was determined according to their shape and abundance. Mineralogical compositions of the unweathered and weathered rhyolite-sulfide orebody complex ( $\mathrm{S}$ and WS) are presented in Table 3. The most superficial expression of weathering of the sulfide orebody is represented by the sample WS2, which comprises a very thin layer of ochreous material. This layer represents the outer part of the WS1 sample, and is mainly composed of schwertmannite (Table 3). The ironpan was found to be composed of either hematite and goethite or goethite only as observed by XRD analyses (Table 3).

In contrast to XRD, Raman investigations allow one to identify noncrystalline phases such as Mn phases observed only at the UA site. The most significant source of $\mathrm{Mn}$ at the UA site is the basalt lens crosscutting the rhyolite. The Mn phases are highly hydrated and are probably noncrystalline. The $\mu$ Raman spectrum only displays a weak broad band around $630 \mathrm{~cm}^{-1}$ that is typical of Mn oxides and hydroxides (Bernard et al. 1993, Israel et al. 1997) (Fig. 2). A similar shape for this spectrum was observed for $\mathrm{Mn}^{3+}$ oxides by Smith et al. (1999), but according to Buciuman et al. (1999), this band could also be due to the transformation of $\mathrm{MnO}_{2}$ into $\mathrm{Mn}_{3} \mathrm{O}_{4}$ under the laser during acquisition of the spectral data. Electron-microprobe results confirm that those Mn phases identified in our samples correspond to hydroxides or hydrated oxides.

At both sites, $\mu$ Raman results suggest the presence of amorphous iron (oxy-)hydroxides and goethite of varying crystallinity. Raman spectra on various goethite-rich areas are shown in Figures 2 a to $2 \mathrm{~d}$. The spectra show broad bands at 298 and $395 \mathrm{~cm}^{-1}$ suggesting poorly or microcrystalline goethite, and sharp peaks, indicative of more crystalline goethite, at 240, 298, 395, 478, 549, 687, 1001, 1116 and 1302 $\mathrm{cm}^{-1}$ (Nauer et al. 1985, Dünnwald \& Otto 1989). The width and the slight shift of some of the Raman peaks may also be attributed to sulfur. In Figure $2 b$, the band at $1001 \mathrm{~cm}^{-1}$, which is shifted to $987 \mathrm{~cm}^{-1}$, and the shoulder at $436 \mathrm{~cm}^{-1}$, are ascribed to the $v_{1}$ and $v_{2}$ vibrational frequencies of the $\mathrm{SO}_{4}{ }^{2-}$ ion, respectively (Nakamoto 1986), or to other trace elements associated with goethite, as confirmed by EPMA data. Hematite is characterized by sharp peaks at $221,290,404 \mathrm{~cm}^{-1}$ and broader bands at 490, 665, 1072 and $1306 \mathrm{~cm}^{-1}$ (De Faria et al. 1997, Pérez- León et al. 2004).

At both sites, Raman spectroscopic results indicate that jarosite or hydroniumjarosite are present (Figs. 2e to $\mathrm{f})$. The typical $\mathrm{SO}_{4}{ }^{2-} \nu_{3}$ vibration is detected at 1105 
THE WEATHERING OF A SULFIDE OREBODY

TABLE 3. BULK CHEMICAL COMPOSITION OF THE MA AND UA SITE SAMPLES

\begin{tabular}{|c|c|c|c|c|c|c|c|c|c|c|c|c|c|c|}
\hline Sample & Mineralogy* & $\mathrm{SiO}_{2}$ & $\mathrm{Al}_{2} \mathrm{O}_{3}$ & ${ }_{3} \mathrm{Fe}_{2} \mathrm{O}_{3}$ & $\mathrm{MgO}$ & $\mathrm{Na}_{2} \mathrm{O}$ & $\mathrm{K}_{2} \mathrm{O}$ & $S_{\mathrm{tot}}$ & LOI & As & $\mathrm{Ba}$ & $\mathrm{Cu}$ & $\mathrm{Pb}$ & $\mathrm{Zn}$ \\
\hline \multicolumn{15}{|c|}{ MA site: waste rock pile, uphill to downhill } \\
\hline WRP1 & $\begin{array}{l}\text { qtz, fsp, jrs, } \\
\text { alu }\end{array}$ & 40.9 & 7.4 & 18.5 & 1.2 & 1.8 & 0.5 & 5.5 & 29.1 & 86 & 166 & 428 & 33 & 147 \\
\hline WRP3 & $\begin{array}{l}\text { qtz, mi, sm, } \\
\text { alu }\end{array}$ & 69.2 & 5.6 & 8.6 & 1.1 & 0.3 & 1.1 & 1.7 & 13.5 & 21 & 166 & 233 & 29 & 82 \\
\hline WRP5 & 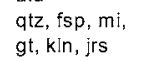 & 36 & 8.6 & 23.7 & 1.0 & 1.5 & 2.5 & 5.8 & 25.3 & 157 & 428 & 83 & 34 & 76 \\
\hline WRPG & $\mathrm{qtz}, \mathrm{sm}$ & 56.8 & 1.5 & 24.6 & 0.6 & b.d.1. & b.d.l. & 1.8 & 16.4 & 14 & 112 & 448 & 23 & 267 \\
\hline WRP7 & $\begin{array}{l}\text { qtz, mi, gt, } \\
\text { hem, jrs }\end{array}$ & 42.4 & 2.5 & 41.8 & 0.3 & 0.1 & 0.6 & 1.5 & 11.6 & 852 & 70 & 330 & 364 & 103 \\
\hline WRP8 & $\begin{array}{l}\mathrm{qtz}, \mathrm{fsp}, \mathrm{mi} \\
\mathrm{gt}^{\mathrm{t}} \mathrm{js}, \mathrm{alu}\end{array}$ & 36.6 & 7.1 & 24.9 & 0.9 & 0.9 & 1.1 & 4.8 & 28.4 & 78 & 424 & 649 & 43 & 450 \\
\hline WRP11 & $\begin{array}{l}\text { qtz, fsp, mi, } \\
\text { gt, jrs }\end{array}$ & 56.4 & 10.6 & 18.3 & 0.5 & 2.7 & 0.8 & 0.7 & 10.3 & 60 & 348 & 230 & 11 & 88 \\
\hline WRP2 & $\begin{array}{l}\mathrm{qtz}, \mathrm{fsp}, \mathrm{kln}, \\
\mathrm{jrs}\end{array}$ & 58 & 9.0 & 12.5 & 0.4 & 2.6 & 1.7 & 3.1 & 15.7 & 52 & 607 & 73 & 120 & 38 \\
\hline WRP4 & $\mathrm{qtz}, \mathrm{mi}, \mathrm{jrs}$ & 45.6 & 9.5 & 19.1 & 0.5 & 2.5 & 1.3 & 4.5 & 21.9 & 94 & 148 & 41 & 16 & 46 \\
\hline WRP9 & $\begin{array}{l}\mathrm{qtz}, \text { fsp, } \mathrm{mi} \\
\mathrm{gt}, \mathrm{jss}\end{array}$ & 40.6 & 7.6 & 30.7 & 0.7 & 1.5 & 1.2 & 2.2 & 17.3 & 63 & 678 & 572 & 33 & 93 \\
\hline WRP10 & $\begin{array}{l}\mathrm{qtz}, \mathrm{fsp}, \mathrm{mi} \text {, } \\
\mathrm{jrs}\end{array}$ & 58.6 & 6.6 & 14.4 & 0.2 & 1.2 & 1.8 & 3.8 & 16.6 & 16 & 477 & 53 & 73 & 30 \\
\hline \multicolumn{15}{|c|}{ MA site: hardpan } \\
\hline HP1 & $\begin{array}{l}\text { qtz, fsp, gt, } \\
\text { jrs }\end{array}$ & 42.7 & 5.3 & 32.0 & b.d.l. & 1.6 & 1.1 & 2.0 & 16.3 & 53 & 739 & 620 & 15 & 148 \\
\hline HP2 & $\begin{array}{l}\text { qtz, fsp, mi, } \\
\text { gt, jrs }\end{array}$ & 43.2 & 8.6 & 27.9 & 0.3 & 2.0 & 0.6 & 1.9 & 14.9 & 96 & 333 & 418 & 27 & 173 \\
\hline $\mathrm{HP} 3$ & $\begin{array}{l}\text { qtz, fsp, chl, } \\
\mathrm{gt}_{\text {t jrs }}\end{array}$ & 49.5 & 11.4 & 21.5 & 1.8 & 2.6 & 0.4 & 0.7 & 10.7 & 41 & 156 & 454 & 11 & 118 \\
\hline \multicolumn{15}{|c|}{ MA site: ochres } \\
\hline $\mathrm{Oc}_{\mathrm{a}}$ & $\begin{array}{l}\text { qtz, gt, sch, } \\
\text { jrs }\end{array}$ & 5.2 & 1.8 & 61.2 & 0.1 & 0.1 & 0.1 & 3.9 & 30.9 & 20 & 46 & 176 & 8 & 64 \\
\hline$O c_{b}$ & $q t z, g t, j r s$ & 8.9 & 2.0 & 61.0 & 0.2 & 0.2 & 0.3 & 5.7 & 26.4 & 57 & 175 & 650 & 28 & 82 \\
\hline \multicolumn{15}{|c|}{ UA site: ironpan } \\
\hline IP1 & $\mathrm{g}$ & 6.2 & 2.6 & 72.4 & b.d.l. & b.d.I. & 0.2 & 1.2 & 18 & 17 & 93 & 621 & 7 & 93 \\
\hline 1122 & $\mathrm{qtz}, \mathrm{mi}$, hem & 57.1 & 10.3 & 22.5 & 0.7 & 0.1 & 2.3 & 0.3 & 8.0 & 15 & 401 & 181 & 6 & 46 \\
\hline IP 3 & $\begin{array}{l}\text { qtz, mi, gt, } \\
\text { jrs }\end{array}$ & 31.3 & 5.7 & 47.0 & 0.2 & 0.1 & 1.2 & 1.0 & 13.6 & 404 & 430 & 939 & 259 & 283 \\
\hline \multicolumn{15}{|c|}{ UA site: rhyolite-sulfide orebody complex ("unweathered") } \\
\hline s1 & $\begin{array}{l}\text { qtz, mi, chl, } \\
\text { py, sp, cp, jrs }\end{array}$ & 64.6 & 14.2 & 7 & 3.2 & 0.6 & 2.4 & 4.5 & 8.2 & 56 & 2308 & 1303 & & 1088 \\
\hline s2 & $\mathrm{qtz}, \mathrm{mi}, \mathrm{chl}$ & 71.9 & 12.9 & 5.4 & 1.2 & 0.1 & 3.1 & 1.8 & 5.0 & 18 & 1798 & 49 & 5 & 49 \\
\hline \multicolumn{15}{|c|}{ UA site: weathered rhyolite-sulfide orebody complex } \\
\hline Ws & & 73.8 & 11.5 & 5.8 & 0.4 & 0.1 & 3.0 & 4.4 & 5. & 19 & 940 & 68 & 5 & 45 \\
\hline wS2 & $\mathrm{qtz}, \mathrm{mi}, \mathrm{sch}$ & 9.9 & 2.7 & 50 & 0.1 & b.d.I. & 0.4 & 5.7 & n.a. & 67 & 301 & 1027 & 4 & 120 \\
\hline
\end{tabular}

* Bulk mineralogy as determined by XRD and polished thin section petrography; b.d.l.: below detection limit; n.a.: not analyzed. Symbols: alu: alunogen; chl: chlorite; cp: chalcopyrite; fsp: feldspars; gt: goethite; hem: hematite; jrs: jarosite or hydronium jarosite; kIn: kaolinite; mi: micas; py: pyrite; qtz: quartz; sch: schwertmannite; sm: smectite; sp: sphalerite. Units: concentrations of $\mathrm{SiO}_{2}, \mathrm{Al}_{2} \mathrm{O}_{3}, \mathrm{Fe}_{2} \mathrm{O}_{3}, \mathrm{MgO}, \mathrm{Na}_{2} \mathrm{O}$. $\mathrm{K}_{2} \mathrm{O}, \mathrm{S}_{\mathrm{lot}}$ and $\mathrm{LOl}$ are expressed in wt.\%, and those of $\mathrm{As}, \mathrm{Ba}, \mathrm{Cu}, \mathrm{Pb}$ and $\mathrm{Zn}$, in $\mathrm{mg} / \mathrm{kg}$.

$\mathrm{cm}^{-1}$ (Nakamoto 1986). Hydroniumjarosite is identified by peaks at $138,224,301,353,433 \mathrm{~cm}^{-1}$ with shoulders at $453,566,624,828,935,1010,1105$ and $1152 \mathrm{~cm}^{-1}$, in accordance with the data obtained by Frost et al. (2006) on natural samples. The two broad bands at 828 and $935 \mathrm{~cm}^{-1}$ may be due to the presence of $\mathrm{Pb}$ and $\mathrm{PO}_{4}{ }^{3-}$, respectively, in the jarosite (Frost et al. 2006). The Raman spectrum of jarosite shows that some of the peaks are slightly shifted when compared to hydroniumjarosite at $137,224,299,384,438,451$, 

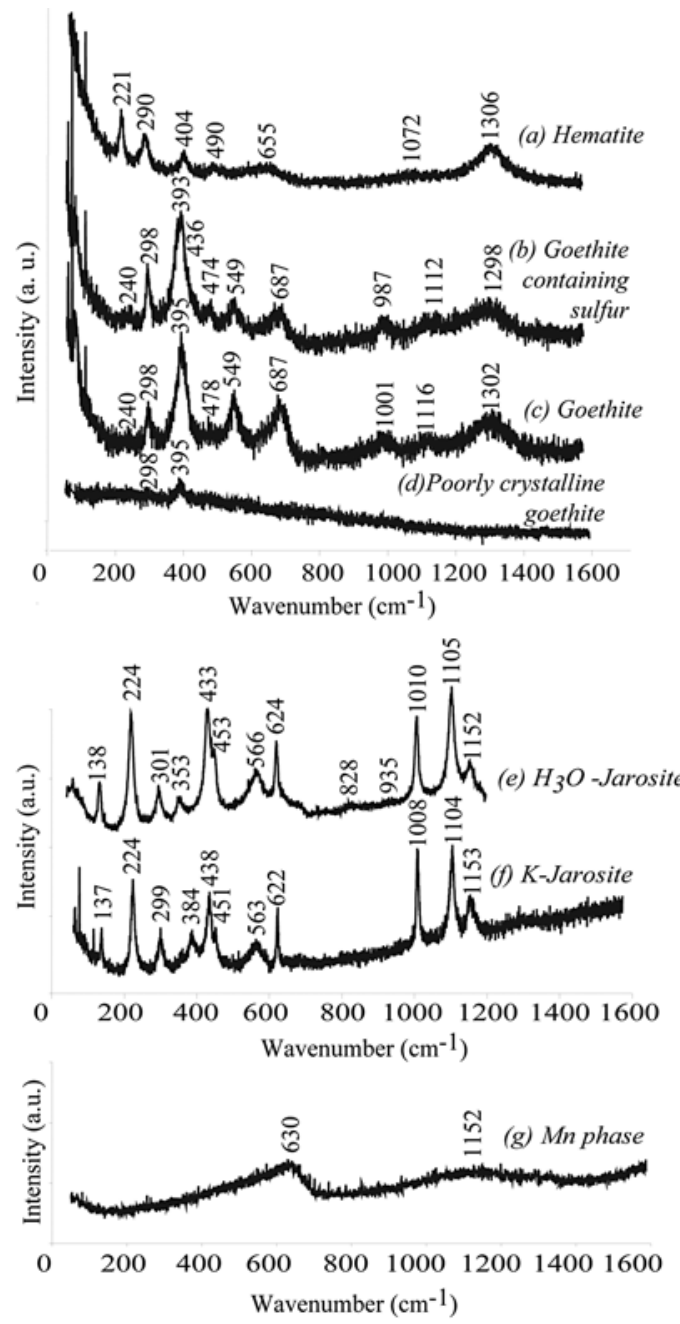

FIG. 2. Micro-Raman spectra (a), (b) and (c) of hematite and various samples of goethite in a specimen taken from the pile of waste rock, (d) poorly crystalline goethite in an ironpan sample from the UA site, (e) hydroniumjarosite in products filling the pore spaces of altered pyrite, (f) spectrum of jarosite in a hardpan sample collected on the MA site, (g) Mn (hydr-)oxides in an ironpan sample from the UA site.

563, 662, 1008, 1104 and $1153 \mathrm{~cm}^{-1}$ (Sasaki et al. 1998, Frost et al. 2006).

\section{Mineralogical Reaction Pathway}

\section{The alteration of sulfides}

According to our findings on mineralogy and chemical composition, sulfides are, not surprisingly, identified as the primary metal and metalloid sources at both locations. The oxidation of sulfide minerals can be promoted either by microbial activity (e.g., Acidithiobacillus ferrooxidans: Bang et al. (1995), Joeckel et al. (2005) or oxidation by $\mathrm{O}_{2}$ and ferric ions (Moses et al. 1987, Antovijenic \& Bogdanovic 2004). The weathering process can generate acidity resulting in the release of metals or metalloids into the environment, as pointed out in several recent studies with environmental conditions similar to our study (Edwards et al. 2000, Dold \& Fontboté 2002, Hammarstrom et al. 2005, Monterroso \& Macias 2005).

Petrographic observations of the few remnant sulfides that have not been mined in the MA site show alteration-induced features. These sulfides have been detected in the rhyolite, hardpan and ochreous deposits, and are pyrite, $\mathrm{Cu}$-rich pyrite and chalcopyrite. In the rhyolite and hardpan formations, the alteration products are only observed where the porosity allows the fluids to circulate in the different materials, with the alteration products filling the pore space (Fig. 3). $\mathrm{Cu}$-rich pyrite is the most abundant sulfide in these formations. Where located in the microfractures, it shows jarosite and a rim of other $\mathrm{Fe}$ (hydroxy-)sulfate alteration products or is completely replaced. Significant P enrichment was measured in jarosite and in Fe (hydroxy-)sulfates by EPMA, with $\mathrm{P}_{2} \mathrm{O}_{5}$ ranging from $6.8 \pm 2.3 \mathrm{wt} . \%$ in P-rich jarosite to $1.5 \pm 0.4 \%$ in the jarosite and 2.4 $\pm 0.5 \%$ in the $\mathrm{Fe}$ (hydroxy-) sulfates. The electronmicroprobe data highlight the association of jarosite with a sulfate-phosphate phase, which shows an extensive substitution of phosphate for sulfate. On the basis of the general formula of jarosite-group phases, $A B_{3}\left(X \mathrm{O}_{4}\right)_{2}(\mathrm{OH})_{6}$ (Stoffregen et al. 2000), the $A$-site occupancy is very low and attributed to $\mathrm{H}_{3} \mathrm{O}$ (which could not be measured by EPMA). The calculated formulas are $\left(\mathrm{H}_{3} \mathrm{O}_{0.7} \mathrm{~K}_{0.3}\right)\left(\mathrm{Fe}_{2.8} \mathrm{Al}_{0.2}\right)_{\Sigma 3}\left[\left(\mathrm{SO}_{4}\right)_{1.7}\left(\mathrm{PO}_{4}\right)_{0.3}\right]$ $\Sigma_{2}(\mathrm{OH})_{6}$ for the low-P jarosite, with $\mathrm{S}$ replaced by $\mathrm{P}$ at the $\left(X_{4}\right)$ sites, and $\left(\mathrm{H}_{3} \mathrm{O}_{0.89} \mathrm{~K}_{0.06} \mathrm{Ca}_{0.05}\right)\left(\mathrm{Fe}_{2.1} \mathrm{Al}_{0.9}\right)$ $\Sigma_{3}\left[\left(\mathrm{SO}_{4}\right)_{0.8}\left(\mathrm{PO}_{4}\right)_{1.2}\right]_{\Sigma_{2}}\left(\mathrm{OH}, \mathrm{H}_{2} \mathrm{O}\right)_{\Sigma 6}$ for the sulfatephosphate phase. The $\mathrm{Ca}$ content of this $(\mathrm{S}, \mathrm{P}) \mathrm{O}_{4}$ phase may originate from the alteration of apatite or Ca-rich feldspar. This chemical data indicate the presence of a phase belonging to the alunite supergroup of minerals, most likely to the crandallite group, with $\mathrm{Fe}>\mathrm{Al}$, according to the nomenclature established by Jambor (1999). Furthermore, the sulfate-phosphate phase, like the jarosite-group minerals, exhibit local enrichments in contaminants, with higher amounts detected in jarosite than in the $(\mathrm{S}, \mathrm{P}) \mathrm{O}_{4}$ phase or $\mathrm{Fe}$ (hydroxy-)sulfates, especially for $\mathrm{Cu}$ and $\mathrm{Pb}$ (Table 4).

Chalcopyrite is the most common sulfide in the ochreous deposits and exhibits features of physical alteration such as cracks and shapes that are more rounded than euhedral. No products of direct alteration or features such as an alteration rim have been identified. This could be explained by the fact that chalcopyrite in these precipitates is invariably embedded in a silicate 


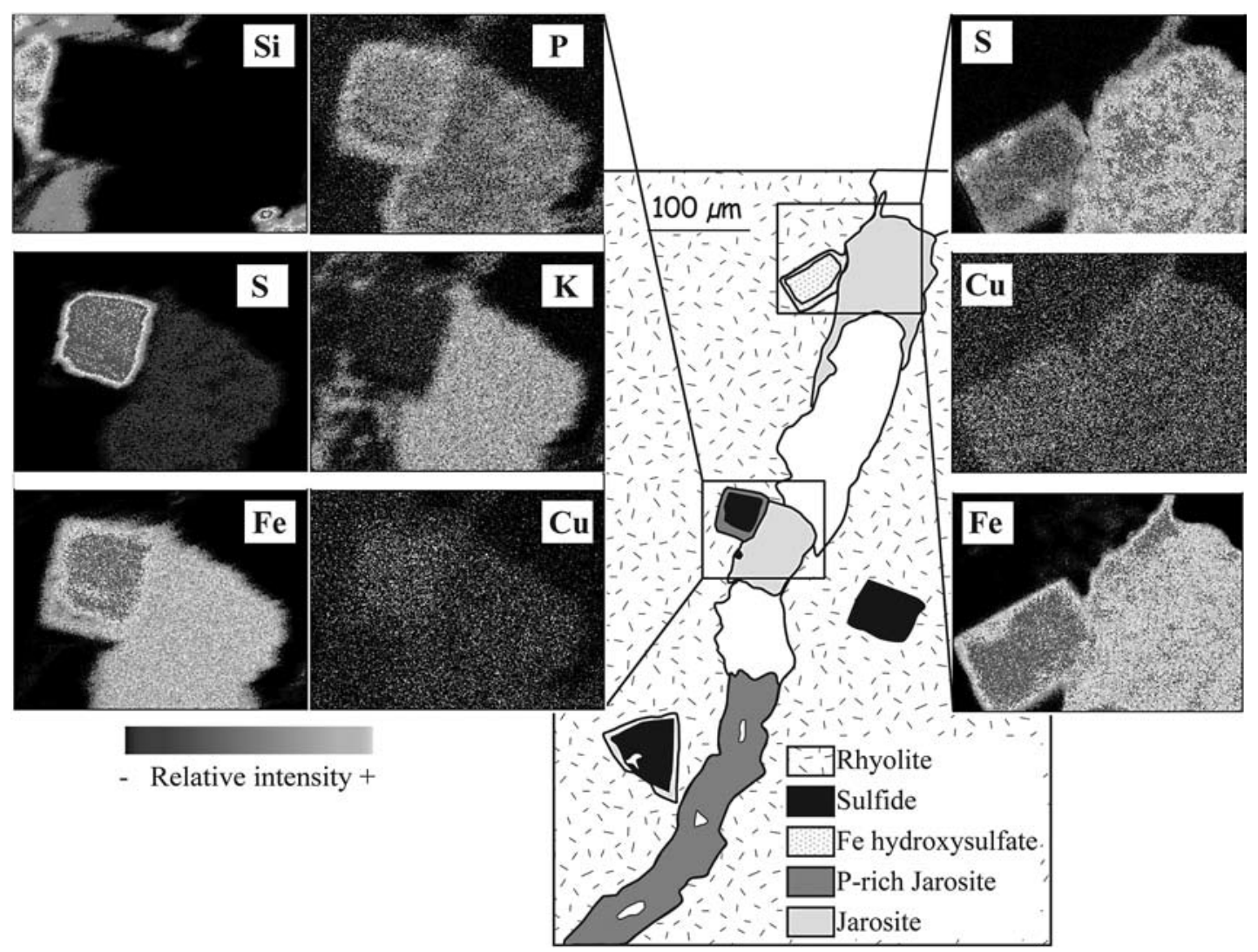

FIG. 3. Schematic representation of the alteration of pyrite and Cu-rich pyrite as observed in the mine-affected site (MA). Only the pyrite located near the pore space is altered. Two areas mapped with an SEM are shown to highlight differences in the weathering between different grains of $\mathrm{Cu}$-rich pyrite: either jarosite associated with the sulfate-phosphate phase, or poorly crystalline to noncrystalline Fe hydroxysulfate precipitate, depending on the degree of alteration.

matrix, which protects the sulfides from weathering processes, as previously reported by Jambor (1994).

At the UA site, unweathered or slightly weathered sulfides have been identified as large grains of pyrite commonly containing (micro-)inclusions of chalcopyrite and sphalerite between 5 and $40 \mu \mathrm{m}$ in size. A micro-SXRF elemental map shows that pyrite also exhibits zoning in As (Fig. 4a), suggesting that As is incorporated in pyrite with an atomic concentration ratio As:S ranging from 0.01 to 0.03 (Table 4). Arsenic is incorporated within pyrite as shown by the $\mu$ XANES spectrum with a peak at $11865 \mathrm{eV}$, which is consistent with $\mathrm{As}^{1-}$ species, as determined by Simon et al. (1999) and Kwong et al. (2007) (Fig. 4c). The alteration of pyrite appears to be limited, as no direct secondary products have been observed, as in the MA site.

No primary sulfide of $\mathrm{Pb}$ or secondary $\mathrm{Pb}$-bearing mineral such as anglesite or plumbojarosite that could be sources of $\mathrm{Pb}$ was observed, in contrast to previous studies (e.g., Jeong \& Lee 2003). In addition, galena was not described in the primary paragenesis as a major sulfide (Clark 1917). However, our observations agree with the sequence of increasing resistance to weathering observed by Jambor (1994) in similar environment to ours and in which galena and sphalerite are less resistant than pyrite, arsenopyrite and chalcopyrite.

\section{Distribution of $\mathrm{As}, \mathrm{Cu}, \mathrm{Pb}$ and $\mathrm{Zn}$ during the weathering of the sulfide orebody}

As discussed above, various carriers of the PTTE have been identified. Among them, three PTTE-bearing phases prevail: (1) Fe (oxy-)hydroxides, (2) sulfates, and (3) Mn (hydr-)oxides.

(1) Metals and metalloids have been found in hematite, goethite and poorly crystalline to noncrystalline Fe (oxy-)hydroxides (HFO). Goethite was identified at both sites and contains higher amounts of metals or 
TABLE 4. TRACE-ELEMENT COMPOSITION OF SAMPLES FROM THE MA AND UA SITES, AS OBTAINED BY EPMA

\begin{tabular}{|c|c|c|c|c|c|c|c|c|c|}
\hline \multirow{2}{*}{$\begin{array}{l}\text { Mineralogy of the } \\
\text { metal-bearing phases }\end{array}$} & & \multicolumn{4}{|c|}{ Mine-affected site (MA) } & \multicolumn{4}{|c|}{ Unaffected site (UA) } \\
\hline & & As & $\mathrm{Cu}$ & $\mathrm{Pb}$ & $\mathrm{Zn}$ & As & $\mathrm{Cu}$ & $\mathrm{Pb}$ & $\mathrm{Zn}$ \\
\hline \multicolumn{10}{|c|}{ Sulfides and immediate products of alteration } \\
\hline \multirow[t]{3}{*}{ Pyrite } & $N$ & 3 & 3 & 1 & 3 & 8 & d.l. & d.f. & 1 \\
\hline & $A v$. & 282 & 233 & 260 & 53 & 7330 & & & 36 \\
\hline & Sto & 99 & 178 & & 18 & 5078 & & & \\
\hline \multirow[t]{3}{*}{ Fe hydroxysulfate } & $N$ & 4 & 4 & 3 & 4 & n.o. & n.o. & n.o. & n.o \\
\hline & Av. & 436 & 1919 & 134 & 128 & & & & \\
\hline & Std & 461 & 310 & 48 & 51 & & & & \\
\hline \multirow[t]{3}{*}{ Jarosite } & $N$ & 5 & 10 & 6 & 5 & n.o. & n.o. & n.o. & n.o. \\
\hline & Av. & 383 & 4240 & 7094 & 114 & & & & \\
\hline & Std & 313 & 3398 & 5725 & 32 & & & & \\
\hline \multirow{3}{*}{ P-rich jarosite } & $N$ & 8 & 8 & 6 & 8 & n.o. & n.o. & n.o. & n.o \\
\hline & Av. & 367 & 841 & 321 & 120 & & & & \\
\hline & Std & 267 & 306 & 197 & 47 & & & & \\
\hline
\end{tabular}

Authigenic phases produced by weathering processes

\begin{tabular}{|c|c|c|c|c|c|c|c|c|c|}
\hline Well-crystallized to & $N$ & 6 & 6 & 6 & 6 & 13 & 9 & 9 & 9 \\
\hline poorly crystalline & $A V$. & 517 & 1349 & 152 & 113 & 4557 & 860 & 211 & 419 \\
\hline Fe (oxy-)hydroxides ${ }^{*}$ & Std & 487 & 743 & 37 & 21 & 3055 & 478 & 80 & 184 \\
\hline Non-crystalline & $N$ & 4 & 5 & 4 & 4 & n.o. & n.o. & n.o. & n.o. \\
\hline Fe (oxy-)hydroxides & $A v$ & 275 & 8315 & 97 & 70 & & & & \\
\hline & Std & 110 & 4626 & 17 & 11 & & & & \\
\hline Jarosite-group minerals & $N$ & 3 & 4 & 4 & 4 & 2 & 2 & d.l. & 2 \\
\hline & $A v$ & 170 & 2743 & 200 & 114 & 351 & 275 & & 421 \\
\hline & Std & 55 & 2486 & 77 & 59 & 103 & 238 & & 30 \\
\hline Mn (hydr-)oxides & $N$ & n.o. & n.o. & n.o. & n.o. & 4 & 12 & 7 & 6 \\
\hline & $A V$. & & & & & 2390 & 7882 & 8551 & 2275 \\
\hline & Std & & & & & 1132 & 1353 & 6772 & 2059 \\
\hline
\end{tabular}

$N$ : number of analyses, Av.: average, Std: standard deviation; n.o.: not observed; b.d.l.: below detection limit. Units of concentration: $\mathrm{mg} / \mathrm{kg}$. * For example, goethite, ferrihydrite.

metalloids (especially As, up to 0.57 wt.\%) in the UA site compared to the MA site (Table 4). Other partially, poorly crystalline or noncrystalline HFO with lower trace-element concentrations have been observed only at the MA site (Table 4). The relationship between As and Fe (oxy-)hydroxides is outlined by the $\mu \mu \mathrm{SXRF}$ derived distribution of elements (Fig. 4b), which also shows that the amount of As associated with Fe (oxy-) hydroxides can vary. Regardless of the Fe phase, As is invariably detected as an $\mathrm{As}^{5+}$ species according to the As $K$-edge $\mu$ XANES spectra, compared to $\mathrm{As}^{5+}$-rich goethite or HFO (Fig. 4c). Micromineralogical maps obtained by SXRD are shown in Figure 4d and reveal some variations in the distribution of goethite (shown at $4.8 \AA$ ) and of HFO (shown at $1.48 \AA$ to avoid overlapping with other goethite peaks). This was already suspected according to slight differences observed on As $K$-edge $\mu$ XANES spectra.

Micro-SXRF results show that $\mathrm{Cu}$ is also associated with a mixture of goethite and HFO (Fig. 5a). The broad XRD peak between 2.8 and $2.55 \AA$ is characteristic of a poorly crystalline HFO-like material (Fig. 5c). The X-ray-diffraction pattern obtained at different locations of the analyzed Fe (oxy-)hydroxides (white square, Fig. 5a) shows variation in the distribution of goethite or HFO. Copper is detected as $\mathrm{Cu}^{2+}$, as shown by the $\mu$ XANES measurements displayed in Figure $5 b$. The $\mu$ XANES spectra differ according to whether $\mathrm{Cu}$ occurs in the $\mathrm{Fe}$ (oxy-)hydroxides or as individual grains, as indicated by $\mu$ SXRF mapping (Fig. 5a). These individual grains were assumed to be $\mathrm{Cu}$ hydroxides, as suggested by EPMA data.

As shown previously, goethite and other poorly crystalline phases are thus very commonly intimately intermixed, regardless of the contaminants with which they may be associated. The mixing between goethite and HFO-like material has only rarely been highlighted, and this has only been possible using $\mu$ SXRD analysis. It is thus very difficult to quantify precisely the amount of metals or metalloids trapped by each of these Fe phases.

(2) The main sulfates identified are jarosite and hydroniumjarosite, in some instances intimately associated with phosphate, and found in the same kind of formation as the iron compounds in the MA site, i.e. in the hardpan and in the ochreous precipitate $\mathrm{Oc}_{\mathrm{b}}$, 

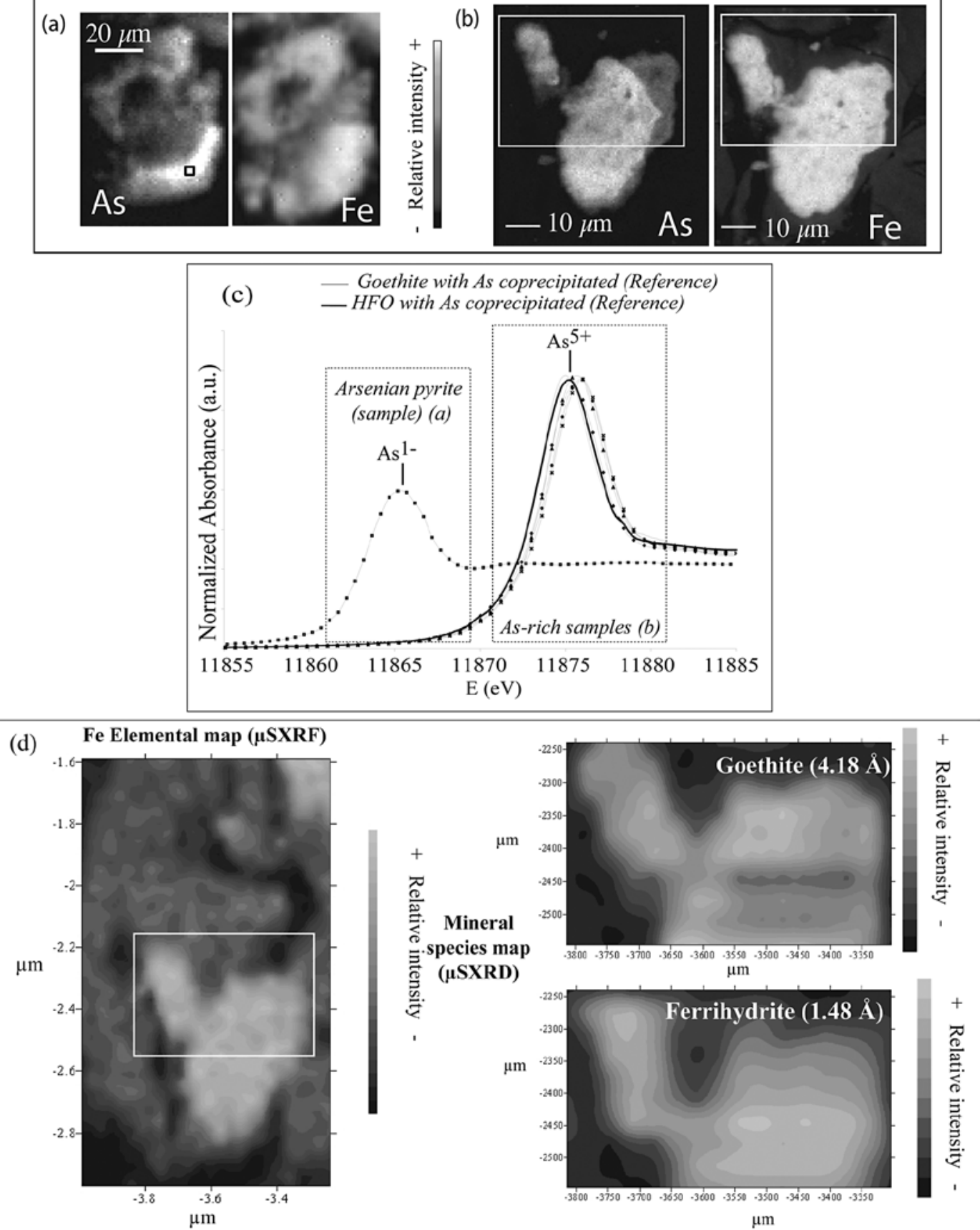

FIG. 4. Micro-focus SXRF elemental map of (a) arsenian pyrite showing zoning in As. The black square represents the area where the As $\mu$ XANES analysis was performed and (b) As associated with a goethite - HFO mixture. The white rectangle symbolizes the zone analyzed by $\mu$ XAS and $\mu$ SXRD. (c) Micro-focused As $K$-edge XANES spectra of the arsenian pyrite sample shown in (a) and different As-rich spectra from sample (b) from the UA site. Micro-XANES spectra of Fe (oxy-) hydroxides (goethite and HFO) synthetic reference material containing coprecipitated As are also displayed; (d) $\mu$-XRF Fe map and $\mu$-SXRD mineralogical map of As-rich goethite - HFO showing the distribution of goethite as detected at its main-intensity diffraction peak (4.18 $\AA$ ) and of HFO at $1.48 \AA$. The white rectangle on the fluorescence maps indicates the analyzed area in (b). Brighter areas correspond to higher concentrations of the analyzed minerals. 

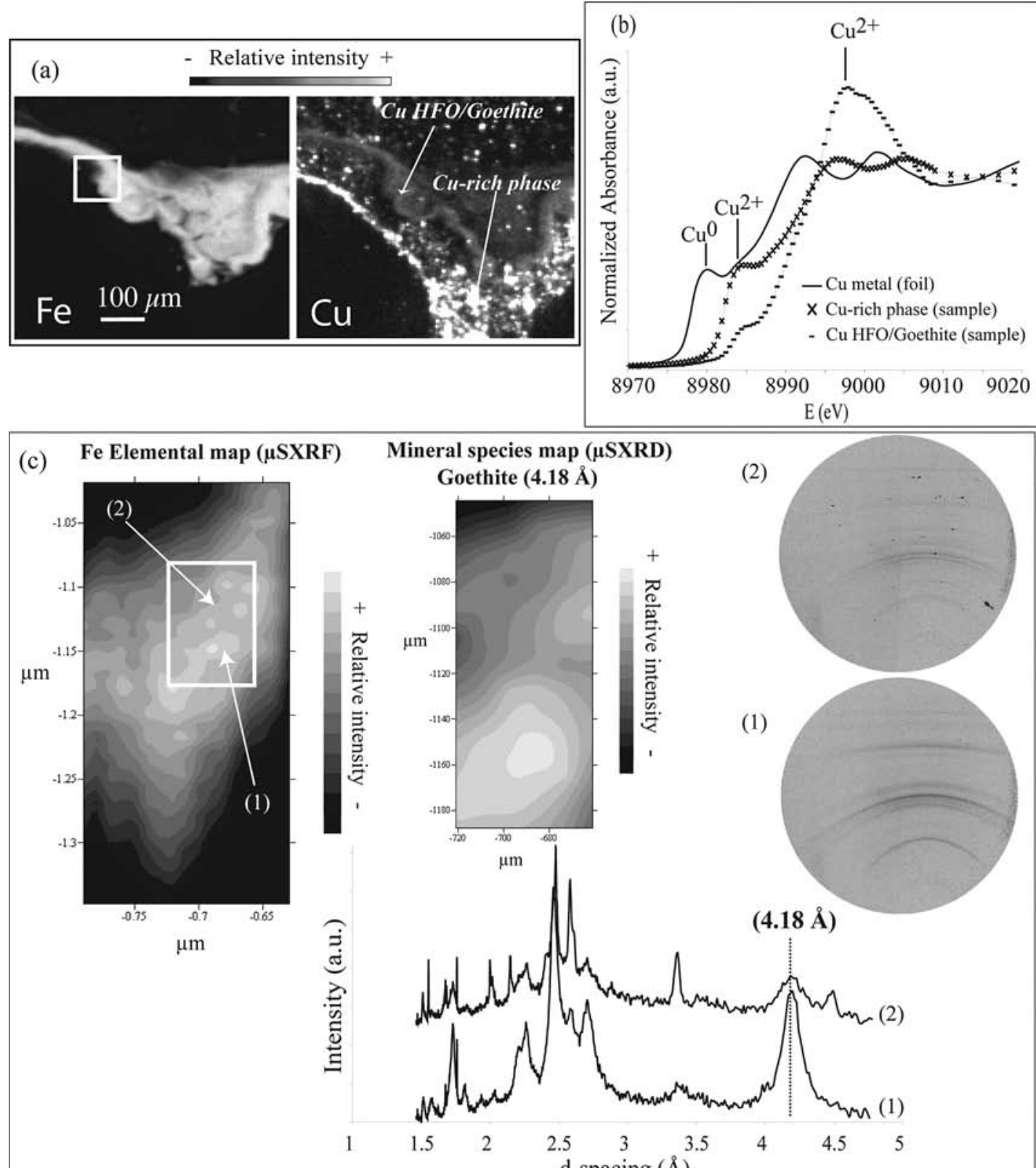

Mineral species map ( $\mu$ SXRD)

Goethite (4.18 $\AA$ )

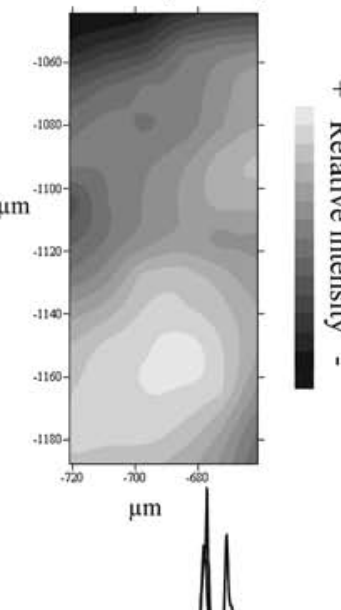

(2)

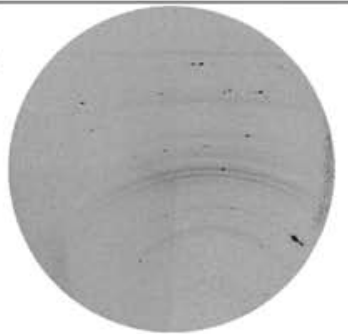

(1)

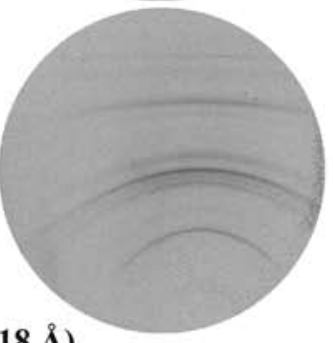

$(4.18 \AA ̊)$

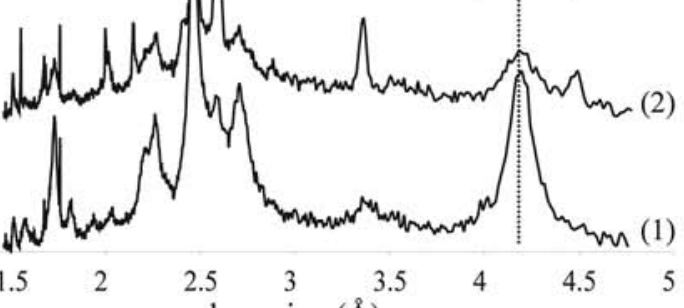

d-spacing $(\AA)$

FIG. 5. Micro-focused SXRF elemental map of (a) $\mathrm{Cu}$ associated or not to Fe phases. The white rectangle represents the area analyzed by $\mu$ SXRD, and the two arrows indicate the area where the $\mu$ XANES analyses have been performed. (b) Copper $K$-edge $\mu$ XANES spectra obtained on the different $\mathrm{Cu}$-bearing phases and on the $\mathrm{Cu}$ foil reference. (c) $\mu$-XRF Fe map (left) and $\mu$-SXRD mineralogical map shown for goethite at $4.18 \AA$. Distributions of goethite and poorly crystalline HFO-like products are shown at (1) and (2) with XRD patterns (location of the analyses on the fluorescence map) and Debye rings illustrating the spatial variation in the crystallinity of the analyzed compound. 
whereas they are less common in the ironpan of the UA site. The jarosite-group minerals may exhibit some enrichment in contaminants such as $\mathrm{As}, \mathrm{Cu}, \mathrm{Pb}$ or $\mathrm{Zn}$ (Table 4). In the runoff channels at the mining site, other temporary sulfates have precipitated as needles (fibrous) and flakes, respectively corresponding to epsomite $\left(\mathrm{MgSO}_{4} \bullet 7 \mathrm{H}_{2} \mathrm{O}\right)$ and to a mixture of epsomite and hexahydrite $\left(\mathrm{MgSO}_{4} \cdot 6 \mathrm{H}_{2} \mathrm{O}\right)$, as documented by $\mathrm{XRD}$. These sulfates have likely formed from $\mathrm{Fe}^{2+}$-poor waters after the oxidation of $\mathrm{Fe}^{2+}$ and its precipitation as $\mathrm{Fe}^{3+}$ oxide or hydroxide minerals and are more soluble than jarosite (Alpers et al. 1994, Buckby et al. 2003) or schwertmannite. Bulk chemical analysis of the epsomite indicates some enrichment of $\mathrm{Cu}(11.7 \mathrm{mg} / \mathrm{kg}), \mathrm{Ni}(9.7$ $\mathrm{mg} / \mathrm{kg}), \mathrm{Pb}(1.3 \mathrm{mg} / \mathrm{kg})$ and $\mathrm{Zn}(80 \mathrm{mg} / \mathrm{kg})$, whereas the concentrations of the same elements in the epsomite hexahydrite mixed material are usually lower $(6.9 \mathrm{mg} /$ $\mathrm{kg} \mathrm{Ni}, 22.7 \mathrm{mg} / \mathrm{kg} \mathrm{Zn}$ ). As these sulfates may dissolve after the first rain, they may release these PTTE to receiving bodies of water.

At the UA site, the surfaces of some of the massive sulfide orebody also exhibit schwertmannite-bearing ochreous precipitates, with high metal contents (e.g., up to $939 \mathrm{mg} / \mathrm{kg} \mathrm{Cu}$ ). Upstream from the MA site in the creek bed (location \#3, Fig. 1), the ochreous deposit Oc a is partially composed of schwertmannite. Bulk chemical analyses performed on $\mathrm{Oc}_{\mathrm{a}}$ and $\mathrm{Oc}_{\mathrm{b}}$ indicate that they contain $\mathrm{As}, \mathrm{Cu}, \mathrm{Pb}$ and $\mathrm{Zn}$, with the highest detected amounts for $\mathrm{Cu}(650 \mathrm{mg} / \mathrm{kg})$. The transformation of metastable schwertmannite $\left(\mathrm{Oc}_{\mathrm{a}}\right)$ into goethite $\left(\mathrm{Oc}_{\mathrm{b}}\right)$ could lead to release of some of these PTTE, according to the qualitative scale of retention proposed by Schroth \& Parnell (2005), $\mathrm{Pb}>\mathrm{Zn}, \mathrm{Mn}>\mathrm{As}, \mathrm{Al}$, and $\mathrm{Cu}$. Acero et al. (2006) also showed that most of the $\mathrm{Al}, \mathrm{Cu}(80 \%)$, As and $\mathrm{Pb}(99 \%)$ remain in the schwertmannite, and Courtin-Nomade et al. (2005) also demonstrated that As is not remobilized during the transformation of schwertmannite to goethite.

Webster et al. (1998) showed that a greater degree of adsorption of $\mathrm{Cu}$ and $\mathrm{Zn}$ occurred on $\mathrm{SO}_{4}$-rich goethite than on schwertmannite. Sample $\mathrm{Oc}_{\mathrm{b}}$ from the MA site contains higher concentrations of PTTE than $\mathrm{Oc}_{\mathrm{a}}$, sampled from the subsurface water outlet. Sample $\mathrm{Oc}_{\mathrm{b}}$ is composed mainly of goethite and has higher amounts of $\mathrm{S}_{\text {tot }}$ than $\mathrm{Oc}_{\mathrm{a}}$; it is possible that the goethite is $\mathrm{SO}_{4}$-bearing and has a greater capacity for the PTTE.

At both sites, iron (oxy-)hydroxides and sulfates are the main intermediate products of weathering. In the MA site, they mainly participate in hardpan formation and the ochreous precipitates (Oc samples), and fill the cracks in the rhyolite. In the UA site, they are observed on the surface, in the ironpan and in the pore spaces of the sulfide orebody complex.

(3) One set of alteration products observed only at the UA site is the Mn (hydr-)oxides. Although they are sparsely distributed in the ironpan, they are very interesting in terms of the amounts of trace elements that they can contain. Micro Mn $K$-edge XANES results indicate that the Mn (hydr-)oxides are mainly composed of $\mathrm{Mn}^{3+}$ with some $\mathrm{Mn}^{4+}$ (Fig. 6a) which confirms and strengthens the $\mu$ Raman data. Scanning electron
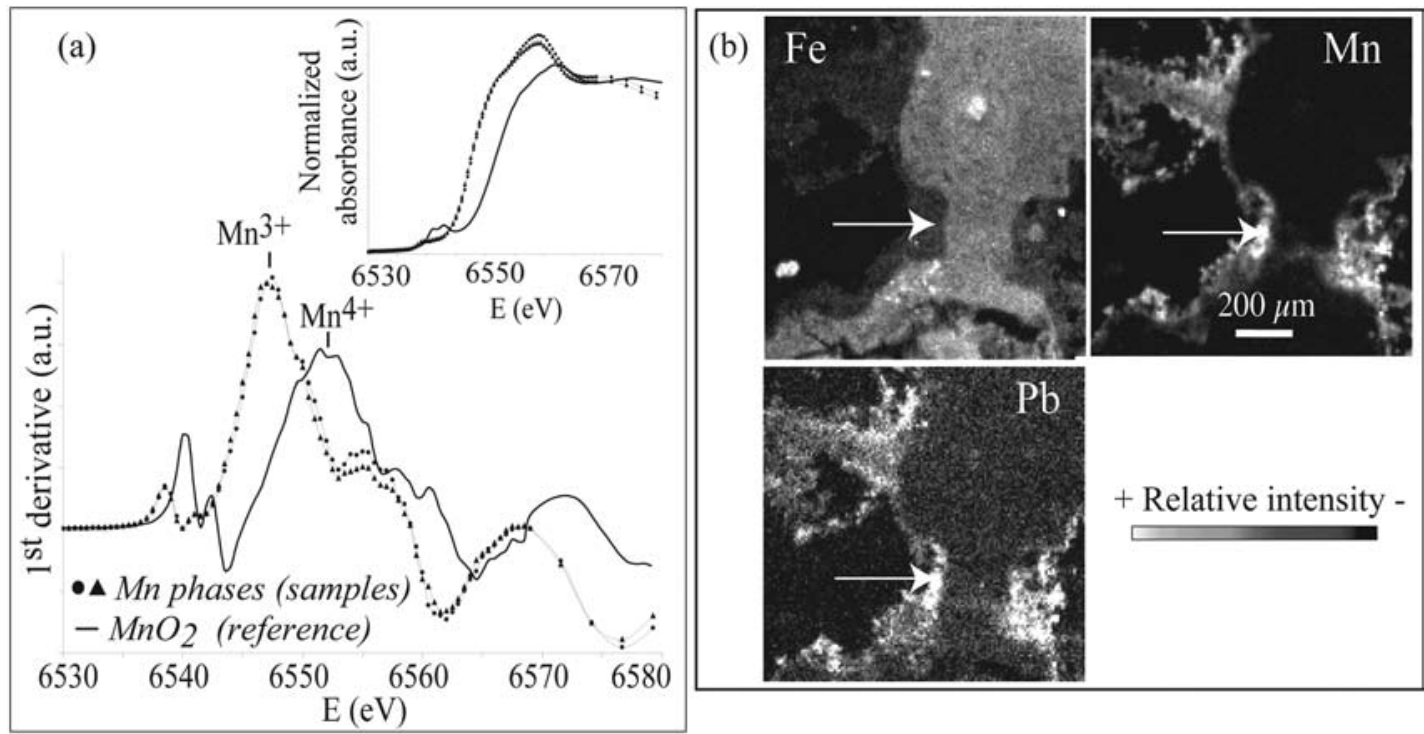

FIG. 6. (a) Manganese $K$-edge $\mu$ XANES (top insert) and first derivative spectra on the area indicated by the white arrows on (b). (b) Micro-focused SXRF element-distribution map showing the distribution of Fe and the spatial correlation between $\mathrm{Mn}$ and $\mathrm{Pb}$. 
microscopy observations and $\mu \mathrm{SXRF}$ show that these $\mathrm{Mn}$ phases are invariably distributed in the pore spaces of the samples, coating the iron (oxy-)hydroxides, as illustrated in Figure 6b. Our EPMA data reveal that the $\mathrm{Mn}$ (hydr-)oxides contain $\mathrm{As}, \mathrm{Cu}, \mathrm{Pb}$ and $\mathrm{Zn}$, with $\mathrm{Pb}$ exhibiting the highest concentrations (up to 1.85 wt.\% PbO, Table 4). This is confirmed by micro-SXRF elemental mapping, which shows that $\mathrm{Pb}$ and $\mathrm{Mn}$ are co-associated (Fig. 6b). Pb $L_{3}$-edge $\mu$ XANES spectra obtained on those phases (not shown here) indicates that $\mathrm{Pb}$ is present as $\mathrm{Pb}^{2+}$.

\section{SUMMARY AND CONCLUSIONS}

The total amount of contaminants discharged to the environment as a result of the weathering of a partially mined sulfide ore body is high. The UA site is a particularly large reservoir as sulfides (the most important source of trace elements) appear to be more abundant here than at the MA site. This is due to physical parameters, including the larger specific surface-area of components of the pile of waste rock and the lower porosity at the UA site. Furthermore, at the MA site, the sulfides were mined out, leading to the current situation, with less sulfides remaining compared to the non-mined site.

The sulfides identified are pyrite, As- or $\mathrm{Cu}$-rich pyrite, chalcopyrite and sphalerite. Arsenic and $\mathrm{Cu}$ may be released after the oxidation of the pyrite and weathering of host-rock basalt, which is summarized chronologically for these sites as follows:

$$
\begin{aligned}
& \mathrm{FeS}_{(2-\mathrm{x})}(\mathrm{As}, \mathrm{Cu})_{\mathrm{x}} \rightarrow(1) \mathrm{Fe} \text { hydroxysulfates } \pm \\
& \mathrm{As},(\mathrm{Cu}), \mathrm{Pb}, \mathrm{Zn} \\
& \rightarrow(2)\left(\mathrm{K}, \mathrm{H}_{3} \mathrm{O}, \mathrm{Pb}\right) \\
& (\mathrm{Fe}, \mathrm{Al}, \mathrm{Cu})_{3}\left(\mathrm{SO}_{4}, \mathrm{PO}_{4}, \mathrm{AsO}_{4}\right)_{2}(\mathrm{OH})_{6} \\
& \rightarrow(3)(\mathrm{Cu}) \text { or } \mathrm{AsO}_{4} *(\alpha-) \mathrm{FeOOH} \text { and } \mathrm{HFO} \\
& \text { Basalt weathering }+\mathrm{PbS} \rightarrow(4) \mathrm{Mn}_{\mathrm{x}} \mathrm{O}(\mathrm{OH})_{\mathrm{y}} \pm \\
& \text { As, }(\mathrm{Cu}), \mathrm{Pb}, \mathrm{Zn}
\end{aligned}
$$

The authigenic sulfates, crystalline to non-crystalline Fe (oxy-)hydroxides and $\mathrm{Mn}^{3+}-\mathrm{Mn}^{4+}$ (hydr-)oxides are the principal PTTE carriers during weathering processes. Arsenic has a high affinity for goethite and $\mathrm{HFO}$, and $\mathrm{Pb}$ is preferentially associated with the Mn (hydr-)oxides. Zinc is homogeneously distributed within the metalbearing phases, whereas $\mathrm{Cu}$ seems to be present only as individual $\mathrm{Cu}$-rich grains (probably $\mathrm{Cu}$ hydroxides) and not incorporated within any other authigenic phases.

Despite the physical and chemical differences between the two sites, iron (oxy-)hydroxides, sulfates and oxyhydroxysulfates are common to both. Manganese (hydr-)oxides have only been observed at the UA site. The sites exhibit a similar mineralogy, but PTTE contents are higher at the UA site, and the sulfides are less weathered here. These features, together with the steep unstable slopes, suggest that UA represents a large reservoir of potential PTTE release.

The distribution and identification of the various metal-bearing phases have only been possible by combining microbeam tools, especially micro-Raman, $\mu \mathrm{XAS}, \mu \mathrm{SXRD}$ and $\mu \mathrm{SXRF}$ mapping techniques.

\section{ACKNOWLEDGEMENTS}

Funding for this study was provided by the national program GDR Transmet (INSU program). We thank Michel Peymirat for the sample preparation, Gary Scott for his help on field trips, and Marilyne Soubrand-Colin, Maxime Vanaecker and Nobumichi Tamura for their assistance during the ALS experiments. The operations of the Advanced Light Source at Lawrence Berkeley National Laboratory are supported by the Office of Science, Basic Energy Sciences, Division of Materials Science of the U.S. Department of Energy under contract number DE-AC02-05CH11231. We thank Professor K.G. Taylor and Dr. K. Hudson-Edwards for handling the reviews of this manuscript, and the two anonymous reviewers and Robert F. Martin for their concise and useful comments.

\section{REFERENCES}

Acero, P., Ayora, C., Torrentó, C. \& Nieto, J.-M. (2006): The behavior of trace elements during schwertmannite precipitation and subsequent transformation into goethite and jarosite. Geochim. Cosmochim. Acta 70, 4130-4139.

Alpers, C.N., Blowes, D.W., Nordstrom, D.K. \& Jambor, J. L. (1994): Secondary minerals and acid mine-water chemistry. In Environmental Geochemistry of Sulfide Mine-Waste (J.L. Jambor \& D.W. Blowes, eds.). Mineral. Assoc. Can., Short Course Handbook 22, 247-270.

AnToviJenić, M.M. \& Bogdanović, G.D. (2004): Investigation of the leaching of chalcopyritic ore in acidic solutions. Hydrometallurgy 73, 245-256.

BANG, S.S., DeshPANDE, S.S. \& Han, K.S. (1995): The oxidation of galena using Thiobacillus ferrooxidans. Hydrometallurgy 37, 181-192.

Bernard, M-C., Hugot-Le Goff, A., Thi, V.B. \& Cordoba DE TORRESI, S. (1993): Electrochromic reactions in manganese oxides. J. Electrochem. Soc. 140, 3065-3070.

Bhumbla, D.K. \& KeEFER, R.F. (1994): Arsenic mobilization and bioavaibility in soils. In Arsenic in the Environment. I. Cycling and Characterization (J.O. Nriagu, ed.). John Wiley \& Sons, New York, N.Y. (51-82).

Brown, G.E., JR., Heinrich, V.E., CASEy, W.H., Clark, D.L., Eggleston, C., Felmy, A., Goodman, D.W., Grätzel, M., Maciel, G., McCarthy, M.I., Nealson, K.H., SverJenSKY, D.A., TONEY, D.A. \& ZACHARA, J.M. (1999): Metal 
oxide surfaces and their interactions with the aqueous solutions and microbial organisms. Chem. Rev. 99, 77-174.

Buciuman, F.C., Patcas, F. \& Hahn, T.A. (1999): A spillover approach to oxidation catalysis over copper and manganese mixed oxides. Chem. Eng. Process. 38, 563-569.

Buckby, T., Black, S., Coleman, M.L. \& Hodson, M.E. (2003): Fe-sulphate-rich evaporative mineral precipitates from the Rio Tinto, southwest Spain. Mineral. Mag. 67, 263-278.

ButLER, T.W., II (2006): Geochemical and biological controls on trace metal transport in an acid mine impacted watershed. Environ. Geochem. Health 28, 231-241.

Clark, C.W. (1917): The geology and ore deposits of the Leona rhyolite. Bull. Dep. Geol., Univ. California Publ. 3, 191-217.

Courtin-Nomade, A., Bril, H., Néel, C. \& Lenain, J.F. (2003): Arsenic in iron cements developed within tailings of a former metallic mine - Enguialès, Aveyron, France. Appl. Geochem. 18, 395-408.

Courtin-Nomade, A., Grosbois, C., Bril, H. \& Roussel, C. (2005): Spatial variability of arsenic in some iron-rich deposits generated by acid mine drainage. Appl. Geochem. 20, 383-396.

Davranche, M. \& Bollinger, J.C. (2000): Release of metals from iron oxyhydroxides under reductive conditions: effect of metal/solid interactions. J. Colloid Interface Sci. 232, 165-173.

De Faria, D.L.A., Venâncio Silva, S. \& DE Oliveira, M.T. (1997): Raman microspectroscopy of some iron oxides and oxyhydroxides. J. Raman Spectrosc. 28, 873-878.

DolD, B. \& FontBoté, L. (2001): Element cycling and secondary mineralogy in porphyry copper tailings as a function of climate, primary mineralogy, and mineral processing. $J$. Geochem. Explor. 74, 3-55.

Dold, B. \& Fontboté, L. (2002): Mineralogical and geochemical study of element mobility in sulfide mine tailings of $\mathrm{Fe}$ oxide $\mathrm{Cu}-\mathrm{Au}$ deposits from the Punta del Cobre belt, northern Chile. Chem. Geol. 189, 135-163.

DünNwald, J. \& ОтTо, A. (1989): An investigation of phase transitions in rust layers using Raman spectroscopy. Corros. Sci. 29, 1167-1176.

Edwards, K.J., Bond, P.L., Druschel, G.K., McGuire, M.M., HAMERS, R.J. \& BANFIELD, J.F. (2000): Geochemical and biological aspects of sulfide mineral dissolution: lessons from Iron Mountain, California. Chem. Geol. 169, 383397.

Fialin, M., Rémy, H., RichaRd, C. \& Wagner, C. (1999): Trace element analysis with the electron microprobe: New data and perspectives. Am. Mineral. 84, 70-77.
Frost, R.L., Wills, R.-A., Weier, M.L., Martens, W. \& MiLls, S. (2006): A Raman spectroscopic study of selected natural jarosites. Spectrochim. Acta A 63, 1-8.

Govindaraju, K. \& Mevelle, G. (1987): Fully automated dissolution and separation methods for inductively coupled plasma atomic emission spectrometry rock analysis. Application to the determination of rare earth elements. J. Anal. At. Spectr. 2, 615-621.

Govindaraju, K., Potts, P.J., WebB, P.C. \& Watson, J.S. (1994): 1994 Report on Whin sill dolerite WS-E from England and Pitscurrie microgabbro PM-S from Scotland: assessment by one hundred and four international laboratories. Geostandard Newsletter 18, 211-300.

GraYMER, R.W. (2000): Digital geologic map and map database of the Oakland metropolitan area, Alameda, Contra Costa, and San Francisco counties, California. U.S. Geol. Surv., Misc. Field Studies Rep. 2342.

Hammarstrom, J.M., Seal, R.R., II, Meier, A.L. \& KornFELD, J.M. (2005): Secondary sulfate minerals associated with acid drainage in the eastern US: recycling of metals and acidity in surficial environments. Chem. Geol. 215, 407-431.

HAURI, J.F., Jr. (2001): Measurement and Manipulation of Copper Speciation and Toxicity in Urban Runoff, Acid Mine Drainage, and Contaminated Discharged Groundwater. Ph.D. thesis, Univ. California, Berkeley, California.

Hudson-Edwards, K.A., Schell, C. \& Macklin, M.G. (1999): Mineralogy and geochemistry of alluvium contamined by metal mining in the Rio Tinto area, southwest Spain. Appl. Geochem. 14, 1015-1030.

http://climvis.ncdc.noaa.gov/

http://xraysweb.lbl.gov/uxas/Beamline/Software/Software. htm

Israel, E.J., Arvison, R.E., WANG, A., PAsteris J.D. \& JolLIFF, B.L. (1997): Lunar and planetary science XXVIII. Lunar and Planetary Science Conf., $28^{\text {th }}$ (Houston), Abstr. 3, P-Z.

JAMBOR, J.L. (1994): Mineralogy of sulfide-rich tailings and their oxidation products. In Environmental Geochemistry of Sulfide Mine-Waste (J.L. Jambor \& D.W. Blowes, eds.). Mineral. Assoc. Can., Short Course Handbook 22, 59-102.

JAMBOR, J.L. (1999): Nomenclature of the alunite supergroup. Can. Mineral. 37, 1323-1341.

Jeong, Gi Young \& Lee, Byoung Yoon (2003): Secondary mineralogy and microtextures of weathered sulfides and manganoan carbonates in mine waste-rock dumps, with implications for heavy-metal fixation. Am. Mineral. 88, 1933-1942. 
Joeckel, R.M., Ang Clement, B.J. \& VAnFleet Bates, L.R. (2005): Sulfate-mineral crusts from pyrite weathering and acid rock drainage in the Dakota Formation and Graneros Shale, Jefferson County, Nebraska. Chem. Geol. 215, 433-452.

Jones, B. \& Renaut, R.W. (2007): Selective mineralization of microbes in Fe-rich precipitates (jarosite, hydrous ferric oxides) from acid hot springs in the Waiotapu geothermal area, North Island, New Zealand. Sediment. Geol. 194, 77-98.

Kwong, Y.T.J., Beauchemin, S., Hossain, M.F. \& Gould, W.D. (2007): Transformation and mobilization of arsenic in the historic Cobalt mining camp, Ontario, Canada. $J$. Geochem. Explor. 92, 133-150.

LALONDE, S.V., AMskold, L.A., WarRen, L.A. \& Konhauser, K.O. (2007): Surface chemical reactivity and metal adsorptive properties of natural cyanobacterial mats from an alkaline hydrothermal spring, Yellowstone National Park. Chem. Geol. 243, 36-52.

Marcus, M.A., MacDowell, A.A., Celestre, R., Manceau, A., Miller, T., Padmore, H.A. \& Sublett, R.E. (2004): Beamline 10.3.2 at ALS: a hard X-ray microprobe for environmental and materials sciences. J. Synchrotron. Rad. 11, 239-247.

Moncur, M.C., Ptacek, C.J., Blowes, D.W. \& Jambor, J.L. (2005): Release, transport and attenuation of metals from an old tailings impoundment. Appl. Geochem. 20, 639-659.

Monterroso, C. \& Macias, F. (2005): Drainage waters affected by pyrite oxidation in a coal mine in Galicia (NW Spain): composition and mineral stability. Sci. Total Environ. 216, 121-132.

Moses, C.O., Nordstrom, D.K., Herman, J.S. \& Mills, A.L. (1987): Aqueous pyrite oxidation by dissolved oxygen and by ferric iron. Geochim. Cosmochim. Acta 51, 15611571.

NachtegaAl, M. \& Sparks, D.L. (2004): Effect of iron oxide coatings on zinc sorption mechanisms at the clay-mineral/ water interface. J. Colloid Interface Sci. 276, 13-23.

NAKAмото, K. (1986): Infrared and Raman Spectra of Inorganic and Coordination Compounds ( $4^{\text {th }}$ ed.). John Wiley \& Sons, New York, N.Y.

Nauer, G., Strecha, P., Brinda-Konopik, N. \& Liptay, G. (1985): Spectroscopic and thermoanalytical characterization of standard substances for the identification of reaction products on iron electrodes. J. Therm. Anal. 30, 813-830.

Pérez-León, C., Kador, L., Zhang, M. \& Müller, A.H.E. (2004): In situ laser-induced formation of $\alpha-\mathrm{Fe}_{2} \mathrm{O}_{3}$ from $\mathrm{Fe}^{3+}$ ions in a cylindrical core-shell polymer brush. $J$. Raman Spectrosc. 35, 165-169.
RAmDohr, P. (1969): The Ore Minerals and Their Intergrowths. Pergamon Press, Oxford, U.K.

Sasaki, K., Tanaike, O. \& Konno, H. (1998): Distinction of jarosite-group compounds by Raman spectroscopy. Can. Mineral. 36, 1225-1235.

Schroth, A.W. \& PARnell, R.A., JR. (2005): Trace metal retention through the schwertmannite to goethite transformation as observed in a field setting, Alta Mine, MT. Appl. Geochem. 20, 907-917.

Schwertmann, U. \& Cornell, R.M. (2000): Iron Oxides in the Laboratory. Preparation and Characterization $\left(2^{\text {nd }}\right.$ ed.). Wiley-VCH Verlag GmbH, Weinheim, Germany.

Serrano, S., Garrido, F., Campbell, C.G. \& GarcíaGONZÁLEZ, M.T. (2005): Competitive sorption of cadmium and lead in acid soils of central Spain. Geoderma 124, 91-104.

Simon, G., Huang Hui, Penner-Hahn, J.E., Kesler, S.E. \& KAO Li-ShUn (1999): Oxidation state of gold and arsenic in gold-bearing arsenian pyrite. Am. Mineral. 84, 10711079 .

SMith, D.C., Bouchard, M. \& Lorblanchet, M. (1999): An initial Raman microscopic investigation of prehistoric rock art in caves of the Quercy district, S.W. France. J. Raman Spectrosc. 30, 347-354.

Stoffregen, R.E., Alpers, C.N. \& Jambor, J.L. (2000): Alunite-jarosite crystallography, thermodynamics, and geochronology. In Sulfate Minerals: Crystallography, Geochemistry, and Environmental Significance (C.N. Alpers, J.L. Jambor \& D.K. Nordstrom, eds.). Rev. Mineral. Geochem. 40, 454- 480.

TAmura, N., PADMORE, H.A \& PATEl, J.R. (2005): High spatial resolution stress measurements using synchrotron based scanning X-ray microdiffraction with white or monochromatic beam. Mater. Sci. Eng. A 399, 92-98.

U.S. Environmental Protection Agency (2002): Drinking water regulations for arsenic and clarifications to compliance and new source contaminant monitoring. EPA816-K-02-018.

Veeresh, H., Tripathy, S., Chaudhuri, D., Hart, B.R. \& Powell, M.A. (2003): Sorption and distribution of adsorbed metals in three soils of India. Appl. Geochem. 18, 1723-1731.

Webster, J.G., Swedlund, P.J. \& Webster, K.S. (1998): Trace metal adsorption onto a acid mine drainage iron(III) oxy hydroxyl sulfate. Environ. Sci. Technol. 32, 13611368. 